\title{
Of College and Community in the Wake of George Floyd
}

\section{Alexander Riley}

Editor's Note: An abbreviated version of the argument made in this piece appears in the November 2021 issue of First Things.

When the verdict was announced in the case of State of Minnesota $v$. Derek Michael Chauvin, the university at which I am employed made an announcement, probably much like those emitted at other colleges and universities around the country. Our campus was informed that the verdict was an indication not of the sound state of justice in the country, "not of how far we have come as a society, but of how far we have to go." We were told that America is a terrifying place for its black citizens, and that the Floyd case demonstrated "the fear and anger that Black Americans experience as part of each day.” Our campus was called to "model inclusivity" and to "tak[e] action" by, for example, "let[ting] a family member know that it's never OK to stereotype people” and by "seek[ing] ways to align with others in everyday life."

The work to address "systemic racial inequity" on our campus and in the country would require "continuous and permanent [italics in the original] work ... to become an antiracist and equitable community." "We, like the rest of our country, have a long way to go," we were solemnly reminded. The message concluded by calling readers to attend "a community gathering to reflect on the Chauvin trial and its implications for the future."

Other invitations to "be in community" were extended from other organizational spaces on campus. One group noted that the "the Minneapolis jury [had] rendered justice in the limited way they could" and asserted a "need [for] a space to release, love, feel, and be in community ... to create a space of compassion, respect, authenticity, courage, and community ... [to] hold space for our community." One administrator chimed in with a message for the campus that signed off cheerily, "In community and solidarity.”

Alexander Riley is Professor of Sociology at Bucknell University whose latest books include Toward a Biosocial Science: Evolutionary Theory, Human Nature, and Social Life (Taylor and Francis, 2021) and Reflecting on the 1960s at 50 (Routledge, 2021); atriley@bucknell.edu. Riley last appeared in AQ in summer 2021 with "Intellectual Affirmative Action." 
I was struck reading these messages, as I often am, by the way the term “community" is used, or rather misused, on the campus where I am employed, and I gather on many others. Community, community, community is everywhere, it seems, or at least everywhere it is in the making, if we will only adhere to the right values.

I was struck too by something else, a similarity between what I discern as the spirit of these messages and their call to community, on the one hand, and that of a document I happened to be reviewing at the same moment as part of my preparation for teaching in the fall semester. But let us pause on that and return to it shortly. First, I would offer a brief reflection on the concept of community, as this is a term with a rich interpretive history, and I am a social scientist who has been teaching the sociological literature on it for some twenty-five years.

In the nineteenth century German thinker Ferdinand Tönnies's classic work on the topic, Gemeinschaft und Gesellschaft (1887-imperfectly translated as Community and Society), he defines the Gemeinschaft as a form of relationship between human wills characterized by the "perfect unity" of the interests of the parties and their mutual investment in a shared moral world. Human beings are, of course, often in conflict, and even when the conflict is not open, they frequently act toward one another as antagonists in the sense that they have differing if not utterly incompatible interests. Social life, and especially economic life in societies with market economies, is characterized by a moral estrangement between interacting individuals in many settings. This indeed is the point of the book Tönnies wrote, as he recognized that the Germany in which he lived, and the Western world more broadly, had been transformed in his lifetime from a world fundamentally defined by Gemeinschaft relations to one in which Gesellschaft, or market, relations ruled.

There were for Tönnies three forms of community, based in relations of blood, of place, and of mind or calling. The Gemeinschaft of the familial unit was the most elemental, the parent-child, husband-wife, and brother-sister relationships obviously typically more intense than any others. Community was produced too by living in close proximity to others for generations and thereby sharing a bond to place and mutual interest in preserving and pacifying it. The third kind of Gemeinschaft emerges from a shared deity or deities and the sacred practices attending the faith, and also from shared labor in pre-modern capitalist economy. 
In all three forms, relations between individuals-fathers and children, lords and peasants, masters and apprentices-are often hierarchical, and sometimes rigorously so. Yet they are not characterized by domination, the crude assertion of power-over. Rather, all in a true community recognize mutuality of goals, and all work in their different capacities and roles toward the same communal end. The child recognizes the parent's deep moral commitment to the familial unit, and ultimately to the ascent of the child to a position atop the hierarchy with the passing of the parent. Apprentices too become masters in time, but only after learning of the necessity of the structure of relations and the moral pedagogy of servitude prior to attainment of the superordinate position. Lords and peasants are in a more permanent form of hierarchy, but here too an organic unity in a whole is the glue that prevents conflicts of interest from becoming egoistic power struggles. Tocqueville, in Democracy in America (1835), provides one of the most sensitive descriptions of the relationships between different status groups in the pre-Revolutionary European aristocracies. While relations between individuals in a democracy are characterized by a seemingly more relaxed, normatively uncircumscribed character, they are also always more distant and potentially hostile than those between unequal individuals in an aristocratic society who are powerfully drawn together by their mutual dependence. In democracies, individuals have little need of one another, whereas in the Ancien Régime, all were bound together in a collective undertaking, the success of which depended on a profound common investment in the established order and its legitimacy. The caricature of lords literally "lording it" mercilessly and cruelly over peasants is largely an invention of the revolutionary enemies of the Ancien Régime, and when it did exist, it was indicative of the breakdown of the system, not the norm of its functioning.

The essential features of community, again, neatly distinguish it from the market relations of modern societies. Gemeinschaft is organic-it emerges from deep features of human nature and has been cultivated over long periods in the soil of that nature and of human experience. It is ancient, extending back to the origins of human social life. It is marked by intimacy and shared identity, rather than the emotional distance and individualism of the Gesellschaft.

Community, I remind you, is what is being claimed in those messages distributed on my campus that I just described. But in which of Tönnies's three forms of Gemeinschaft can we reasonably classify what they are describing? These are not communities of blood and family, clearly. Neither are they 
communities of place. On most campuses, including ours, at least some students commute to campus, and even those who are in residence leave in the summer to go to the place they rightly call "home.” And no faculty or administrators have the relationship to the place of campus that Tönnies describes, either.

There was a time when the students and the faculty at a college could be spoken of as an intellectual community in Tönnies's third sense, but that time is long gone now. There is no longer a unified intellectual calling in universities. Divisions and departments are split into a hodge-podge of disparate, disconnected bodies, competing for funding and students, more and more adrift from any common and basic sense of intellectual mission. Recently, on my campus, a faculty member unironically spoke of the core mission of the university as having to do with two equal pursuits: knowledge and justice. It was understood that when he typed "justice," he inferred the "social” before it. It was likewise understood, by anyone who has been paying attention to higher ed in recent years, that he, along with many of his colleagues here, believe that the second of the two pursuits ultimately must trump the first, and indeed any truth to be pursued must fit a priori with the value of social justice to merit being pursued at all. This is, to put the matter baldly, hardly how universities perceived themselves even fifty years ago.

But is a "calling" to the establishment of woke social justice sufficient for a shared notion of community? The test here is to compare this to the forms of community delineated by Tönnies. Social justice rejects the very notion of hierarchy as illegitimate, so here is a profound difference with respect to traditional community. What of "perfect unity” of interest and moral purpose? This is harder to gauge. Unity is certainly claimed with some frequency by the authorities who promote social justice as the definition of calling in universities. But the reality is something else. Power-over is the basic modus operandi of Diversity, Equity, and Inclusion in higher education. Those who do not willingly join the cause, who perhaps insist on continuing to adhere to the old virtue of truth as the defining characteristic of the calling, or who ask inconvenient questions or demand proof of social justice claims, are bullied and badgered into compliance. The list of these victims of the DEI regime grows daily. Professors who read aloud the racial epithet beginning with the letter " $n$ " from scholarly or literary works assigned in their classes, or who dare to discuss empirically verified facts about black underachievement in higher education on Zoom calls with colleagues after classes have concluded and students have logged off, or 
who criticize the overreach of diversity regimes at their institutions, and a long list of others have found themselves out of work and publicly shamed as racists and worse.

There has been much interest in intellectual quarters of late in the spirit of the totalitarian. Writers such as Anne Applebaum and Ruth Ben-Ghiat have written best-selling books lamenting the rise of nationalism and populism and fretted over their seemingly inevitable link to forms of polity that erase the will of the individual under the weight of beliefs and behaviors imposed from above. The fascists and authoritarians they fear, however, did not invent totalitarianism. Lenin and revolutionary communist Bolshevism did that. In new biographies of the Bolshevik mass murderer, Stéphane Courtois and Victor Sebestyen have made this devastating case at length. And during Lenin's lifetime and in his wake, the utopian communism of the revolutionary left wielded a perverted notion of" "community" as a weapon, and it did it by defining the community in a cultish sense, as a fully unified, monolithic group fused under the charismatic, quasi-religious power of a great and totalitarian leader.

Here is the cue to return to the course I was preparing as I read these email messages from my university’s administration. As it happens, the course deals with the propensity of Western intellectuals to buy into political totalitarianism. One of the key texts in the course, Political Pilgrims, written by my late friend Paul Hollander, describes, among other disturbing mechanisms, how lies about deep "community" in the Soviet Union were taken at face value by otherwise critical Western intellectuals, and then mobilized as evidence of the moral superiority of communist society.

Another source I have students consult in the course is one I have listened to literally dozens of times, but that I make a practice of going through afresh every time I teach the course. It is the harrowing recording made in the final minutes of Jim Jones's Peoples Temple.

Jim Jones, in his paranoia and urge to control, frequently recorded the goings-on of public addresses at Jonestown in Guyana, and he did the same on the last day of the existence of Peoples Temple. In that recording, one listens in disbelieving horror at his lisping ranting, his paranoid fantasies, his evidently insane conspiratorial view of the world and of his role in world liberation. It is an anguishing artifact to which to bear witness. The most difficult part, for me at least, is the part in which, for the only time during the preparation for the mass murder/suicide, Jones is challenged by a lone voice. 
That voice belonged to Christine Miller, a sixty-year-old black woman who was born in Texas and who had come from Los Angeles to join Peoples Temple. She was alone, without family, in Jonestown. In a twenty-minute segment of that final recording, she presents the only opposition made to Jones's desire to destroy the entire group. "We are not committing suicide. It's a revolutionary act," he absurdly intones. Miller patiently and repeatedly asks him for a justification of such an act. She reminds him of an earlier lie in which he claimed that the Soviet Union had indicated a willingness to save Peoples Temple from capitalist aggression: "Is it too late for Russia?" Only a handful of members of the group had deserted, Miller argued. How could this justify the destruction of the whole community? Jones has no real answer. He stalls, he repeats her words, making time for others to recognize their opportunity to jeer and attack them. "I have twelve hundred people's lives in my hands ... I'm going to tell you, Christine, without me, life has no meaning. I'm the best thing you'll ever have ... I'm not talking about self-destruction. I'm talking about that we have no other road."

Miller asks him about the children: "I think they deserve to live, you know?" Jones's reply is chilling: "I agree. But also they deserve much more; they deserve peace." Eventually, what Jones has been endeavoring to produce comes to pass, and others in the group form a bullying mob and begin to challenge Miller. Voices from the crowd shout derisively at her. A man then authoritatively declares: "Christine, you're only standing here because he was here in the first place. So I don't know what you're talking about, having an individual life. Your life has been extended to the day that you're standing there because of him." The crowd applauds him. A woman shouts accusatively from the crowd: "I think you're afraid to die.” Then another male voice calls out, in an emotional, weeping voice: “We're all ready to go. If you tell us we have to give our lives now, we're ready. All the rest of the sisters and brothers are with me."

Something has inexorably shifted. Miller now knows she has lost, and she succumbs, tragically, despondently, heartbreakingly. Jones makes the observation-perfectly consistent with today's woke antiracist ideologues-that the "betrayers" of Peoples Temple were not the blacks he is calling to die with him, but "mostly white people." A litany of twisted testimonies to "Dad” follow.

1 Roughly 70 percent of the Peoples Temple members living in Jonestown were black, but nearly 25 percent were white. A number of the most outspoken defectors who had mobilized to get authorities to investigate were white, and Jones's fury at what he saw as the betrayal of this group was palpable. 
Then, startlingly, Miller herself, nearly weeping, breaks and ends her questioning, falling into total acquiescence: “Thank you for everything. You are the only. You are the only. And I appreciate you.” A woman remarks: "I just want to say something for everyone that I see that is standing around or crying. This is nothing to cry about. This is something we could all rejoice about. We could be happy about this." Another unidentified woman exclaims: "No other way I would rather go than to give my life for Socialism, Communism and I thank Dad very, very much."

Then Jones concludes, in the same lugubrious celebration of victimhood as primary value that anyone in a university today witnesses on a daily basis:

It's never been done before, you say. It's been done by every tribe in history facing annihilation. All the Indians of the Amazon are doing it right now. They refuse to bring any babies into the world. They kill every child that comes into the world. Because they don't want to live in this kind of a world.... Death is a million times preferable to ten more days of this life. If you knew what was ahead of you, you'd be glad to be stepping over tonight. Death is common to people. And the Eskimos, they take death in their stride. Let's be dignified. If you quit telling them they're dying . . Adults, I call on you to stop this nonsense. I call on you to quit exciting your children when all they're doing is going to a quiet rest.... Are we black, proud, and free, or what are we? ... No, no sorrow. It's all over. I'm glad it's over. ...We are free from the hands of the enemy. Hurry, my children. Hurry . . . No more pain now. No more pain ... Take our life from us. We laid it down. We got tired. We didn't commit suicide; we committed an act of revolutionary suicide protesting the conditions of an inhumane world.

Jones was quoting another figure in the revolutionary movements of his time when he invoked the concept of "revolutionary suicide." This had been the title of a book by the Black Panther founder Huey Newton, in which the avowedly Marxist-Leninist Newton, citing the Russian intellectual apologist for anarchist terror and violence Mikhail Bakunin, stated his belief that "the first lesson a revolutionary must learn is that he is a doomed man."

As I listened to Jones and Miller and thought about what was happening on my campus, I fell upon an eerie connection. Here at my university, just a few years ago, on the thirty-fifth anniversary of the murders at Jonestown, there 
was a conference on Peoples Temple, Jim Jones, and racial justice in America. ${ }^{2}$ In its keynote address, a professor of religious studies, Rebecca Moore, described Peoples Temple in the following words: "Peoples Temple was, first and last, an African American institution ... a political movement that emerged out of the matrix of Black Power in the 1960s and 1970s." The meaning of the organization centered, in her reading, on "the positive need to fight, and even to die, for the cause." That is to say, the very essence of Peoples Temple was "framed in the vocabulary of martyrdom ... [and] the members of Peoples Temple saw themselves as true martyrs in the cause of African American liberation.”

Moore celebrated the "militant style of expression" in radical Black Power literature that had informed the disposition of Peoples Temple on race politics in the United States. She described a play, Black Ice, which features the kidnapping and assassination of a congressman: "At the end of the play, Martha shoots the congressman. The last line is 'You didn't die very well!' I never hear these lines without thinking of Congressman Leo Ryan.” Ryan was murdered by members of Peoples Temple at Guyana on the day of the mass murder/suicide.

The members of Peoples Temple sent their own children to death, but Moore rationalized this by reference to Toni Morrison's novel Beloved, in which the character Sethe slits the throat of her own child to keep her from slavery. "She had to be safe," Morrison's character pronounces, “and I put her where she would be.” Moore concluded her remarks by referring to Jonestown as "a dream deferred.” Her words here merit quoting at length:

Self-sacrifice was required to participate in the struggle. This self-denial encompassed not only martyrdom at the hands of the oppressors, but also self-murder, if the death promoted a larger cause or purpose ... The revolutionary suicide of Jonestown was the best weapon that the weak could use against the strong. The people maintained their integrity by dying what they hoped would be a noble death in a cause greater than themselves.

The student newspaper on my campus did several stories on the 2013 Jonestown conference, which was sponsored by the Griot Institute for the Study of Black Lives and Culture. In one of the stories, a student described

2 The conference can be viewed at the following link: https://jonestown.sdsu.edu/?page_id=40139. 
her appreciation for the event, noting, presumably without irony, that it "dispel[led] the notion that Peoples Temple members were crazy, Kool-Aid drinking cultists."

Peoples Temple failed, utterly, horrifically, inhumanly, monstrously. But, dreadful though it is to say, the utopian totalitarianism that Jim Jones practiced in his cult did not die with it. It existed outside Jonestown, in some of the movements and other cultic groups that emerged from the troubled late 1960s, and it has survived to this day. It is now ascendant in America's institutions of higher education.

"Community" at Jonestown is neatly encapsulated in what happened to Christine Miller in those twenty minutes. A decision had been made by the authorities, a decision that in its extremity obviously opened itself to questioning. That no one but Miller asked any questions is already an indication of how perverse this “community” was in its essence. Legitimate authority in Tönnies's description is not a license to drive others, and indeed the entire community, to destruction. It is the sacred trust given to those who sit atop the hierarchy to guide the whole in light of the shared interest of the whole, and with the ultimate goal of the maintenance of the life and the spirit of the whole. In a true community, there would have been many Christine Millers at Jonestown. But instead there was one, and that one was bullied and threatened and eventually shouted down and forced to acquiesce in the suicidal directive of the leader. And in a true campus community, there would be many voices challenging and pushing back against the increasingly radical transformations being imposed on curricula, hiring and promotion procedures, student recruitment and cultivation in the wake of the George Floyd Revolution. But there are few, nearly none, and those that do manifest face the same bullying response Christine Miller faced.

A few years ago, a small group of faculty at my campus-a group that included myself-were sufficiently concerned about the clear trend in narrowing of the spectrum of expressible thought on college campuses that we decided to speak up about it. Inspired by the effort at several prestigious schools in the summer and fall of 2016, and especially by a statement by the University of Chicago to incoming students that was getting some attention at that time, we submitted to our colleagues a brief statement of commitment to free inquiry, embrace of open debate, and rejection of emotional appeals to silence arguments. In a full faculty meeting, the motion and our intentions 
were mendaciously caricatured and attacked. The only substantive thing that was said regarding free expression at the meeting involved an opponent of our motion citing his fear that it would somehow give cover to hypothetical religiously conservative students who reject the scientific consensus on the age of the universe to actively disrupt his cosmology class.

In other words, the most pertinent danger on campuses with respect to free expression was not the threat of radical students baselessly accusing legitimate speakers and perspectives of "white supremacy" and "fascism" and acting to physically prevent those speakers and perspectives from being heard, a phenomenon of which we have seen innumerable examples in recent years, but that of religiously conservative students shouting down science in a science class, actual examples of which there are none in contemporary higher education.

When one of our group tried to defend our motion against an egregiously inaccurate mischaracterization, one of our colleagues who had been jeeringly opposing our motion glared at us and sneered: "Who are you afraid of?" I wish I could believe that he, and the others who cheered his remark, genuinely did not know the obvious answer to that question. On other occasions, I have heard this same jeering colleague speak, in a tone indistinguishable from that of those who wrote to the campus in the wake of the Chauvin verdict, of the Bucknell community, and of how essential it is to nurture it, and of how welcoming and healing it is.

It should not need to be said, but I say it anyway: Of course, the parallel here is yet inexact. Mass suicides are not being ordered on college campuses. Essential social institutions, however, are being warped and distorted so radically that they cannot survive. And the lives of real people are being morally blunted and crushed. Who feels confident predicting where it ends? In any event, it need not end precisely where Jonestown did to constitute a terrible blow to human thriving.

There are some Christine Millers left in the universities, though it is not clear how many. There are many more decent faculty members who will not shout them down, but who will also do nothing to support them, to bolster them under the pressure of the large and steadily growing number of their colleagues who readily perform the function of the man who helped shut Christine Miller down by asserting her utter dependence, for her life, on the ideological totalitarians. I would be lying if I said I never worry that in writing and telling the truth about the place in which I am employed, in telling of its ongoing collapse 
and its utter falling away from the liberal arts ideal that attracted me to the professorial world in the first place, that I will suffer and lose my livelihood and my calling and my ability to support my family. How awful it has been to watch as even people I considered allies in the task of trying to preserve the liberal arts fell into compliance or acquiescence to these new totalitarians.

What happened to real community? Tönnies gave an incomplete answer, looking fundamentally to the way market relations distance individual wills, pit interests mercilessly against one another. He was not wrong, but he died too early to see the birth of a kind of politics that took real community explicitly into its sights and emptied both barrels into it. The progressive left has systematically assaulted community now for more than a century, and wokeism is its latest, most venomous incarnation. The progressives are the ones who have tirelessly assaulted the family, the village and the neighborhood, the church, and the old guilds that humanized relations of work. They have worked ceaselessly for a century or more to crush community. And now, in a final flourish, they cynically and strategically mobilize the term as yet another weapon with which to bludgeon traditional human relations and tear us apart into warring, eternally opposed identity groups. At Peoples Temple, the revolutionary suicide involved the extermination of individual human wills. In Peoples Temple University, it is community, Tönnies's Gemeinschaft, that is put to death, and in the false mobilization of its rhetoric to legitimate the crushing of dissent, the very idea of higher education. 